Grzegorz Tylec

John Paul II Catholic University of Lublin

ORCID: 0000-0003-2016-4523

grzegorztylec@kul.lublin.pl

\title{
Derogation from Copyright Protection Based on the Implementation of Freedom of Information and of Media. Notes on the Judgement of the European Court of Justice of 29 July 2019 in the Proceedings between Funke Medien NRW GmbH and Bundesrepublik Deutschland
}

\section{Odstępstwa od ochrony prawa autorskiego z uwagi na realizację} wolności informacji i wolności prasy. Uwagi na tle wyroku Trybunału Sprawiedliwości Unii Europejskiej z dnia 29 lipca 2019 r. w sprawie pomiędzy Funke Medien NRW GmbH a Bundesrepublik Deutschland

\section{SUMMARY}

Public discussion in 2018, concerning the European Parliament, passing the Directive on copyright and related rights in the Digital Single Market, in the public discourse referred to as ACTA 2, evoked huge social emotions. The source of the conflict were two colliding values: the need to protect copyright and to ensure economic interest of authors and freedom of expression (freedom of the Internet), particularly important for users of works and Internet users. The decisions of the European Court of Justice, given on 29 July 2019 in the proceedings between Funke Medien NRW GmbH and Bundesrepublik Deutschland and the coincident decision in the case Spiegel Online GmbH vs Volker Beckow, deals with the above-given conflict of values. This article provides a description of the main arguments of the above-mentioned judgements of the ECJ and points at their consequences in the scope of changing the current interpretation of the provisions of copyright. The article also contains remarks on the influence of these decisions and their consequences for the disabling of content by providers of content-sharing service providers which violates freedom of expression considering the new Directive of 17 April 2019. The author presented arguments confirming that the Directive (EU) 2019/790 of 17 April 2019 on copyright and related rights in the Digital Single Market and the new way of interpreting copyright rules provided by the judgements of the ECJ has significantly changed the hitherto may of perceiving the rules of permissible use of works.

Keywords: copyright; human rights; freedom of expression; intellectual property 


\section{INTRODUCTION}

For some time now, both court decisions and legal literature have seen the appearance of the issue of the mutual conflict of protection under copyright and freedom of expression (freedom of information and freedom of media) ${ }^{1}$. Situations, when copyright collides with freedom of expression, seem to be inevitable every time information is expressed in an original, creative way ${ }^{2}$. As proof that the principle of freedom of expression is a value which, in certain situations, can prevail over the need to protect copyright, literature gives the example of the decision of the European Court of Human Rights (hereinafter: ECHR) of 10 January 2013 in the case Ashby Donald and others vs France ${ }^{3}$, which stated that a "national" decision which recognises a violation of copyright can be found to violate an individual's right to freedom of expression as of Article 10 of the European Convention for the Protection of Human Rights and Fundamental Freedom (hereinafter: ECHR) ${ }^{4}$ unless the restriction in this area was "necessary in a democratic society" (as provided by Article 10 (2) ECHR).

\section{DESCRIPTION OF THE CASE FUNKE MEDIEN NRW GMBH VS BUNDESREPUBLIK DEUTSCHLAND}

The issue of a mutual collision of copyright and freedom of expression is the essence of two decisions of the European Court of Justice (hereinafter: ECJ) given on the same day. This study presents only the decision in the case Funke Medien NRW GmbH vs Bundesrepublik Deutschland ${ }^{5}$. The description of the other case,

1 Cf. J. Barta, R. Markiewicz, Prawo autorskie a swoboda wypowiedzi i twórczości, [in:] Wspótczesne problemy prawa handlowego. Księga jubileuszowa dedykowana prof. dr hab. Marii Poźniak-Niedzielskiej, red. A. Kidyba, R. Skubisz, Warszawa 2007, pp. 17-28; D. Voorhoof, Copyright vs. freedom of expression, http://echrblog.blogspot.com/2013/01/copyright-vs-freedom-of-expression. html [access: 5.08.2019]; R. Danay, R. Jacob, Copyright vs. Free Expression: The Case of Peer-to-Peer File-Sharing of Music in the United Kingdom, "8 Yale Journal of Law \& Technology" 2005, No. 32.

2 An extensive list of bibliography on this subject is given by J. Barta and R. Markiewicz (Prawo autorskie a swoboda wypowiedzi..., p. 17, footnote 2 ).

3 Complaint No. 36769/08.

4 European Convention for the Protection of Human Rights and Fundamental Freedoms of 4 November 1950 (Journal of Laws 1993, No. 61, item 284 as amended). Article $10 \S 1$ of the Convention, which deals with freedom of expression, guarantees freedom to express opinions and to receive and impart information. This right includes freedom to hold opinions and to receive and impart information and ideas without interference by public authority and regardless of frontiers.

5 Judgement of ECJ (Grand Chamber) of 29 July 2019, Funke Medien NRW GmbH vs Bundesrepublik Deutschland, C-469/17, ECLI:EU:C:2019:623. 
settled on the same day by the ECJ - Spiegel Online GmbH vs Volker Beck ${ }^{6}$, has to be left out because of the limited volume of this study. It should be noted, however, that despite different factual circumstances, in both cases the conclusions of the Court and their justifications are almost identical.

The decision given in the proceedings between Funke Medien NRW GmbH and Bundesrepublik Deutschland concerned the following factual circumstances: the plaintiff, the company Funke Medien operating the website of the German daily newspaper "Westdeutsche Allgemeine Zeitung" on 27 September 2012 applied to state authorities for access to all weekly reports drawn up by the Federal Republic of Germany between 1 September 2001 and 26 September 2012 on the military situation concerning the operations of the Bundeswehr abroad and on the development of the situation within the operation area ("Unterrichtung des Parlaments", "Information for Parliament"; hereinafter: UdP). That application was refused by the competent authorities on the ground that disclosure of the information in those UdPs could have adverse effects on security-sensitive interests of the Federal armed forces. In that context, the authorities pointed out that they published shortened versions of UdPs, called "Unterrichtung der Öffentlichkeit" ("Public Briefings"), that are available to the public without any restrictions. However, Funke Medien obtained, by unknown means, a large proportion of the UdPs, which was published in parts as the "Afghanistan Papiere" ("The Afghanistan Papers") and could be read online as individually scanned pages accompanied by an introductory note, further links and an invitation for comments.

The Federal Republic of Germany, taking the view that Funke Medien infringed its copyright over the UdPs, brought an action for an injunction against Funke Medien, which was upheld by the Landgericht Köln (Regional Court, Cologne, Germany). It was decided that the UdPs could be protected under copyright as "literary works" and they are not official texts excluded from the protection of that law. An appeal by Funke Medien was dismissed by the Oberlandesgericht Köln (Higher Regional Court, Cologne, Germany). The case was brought to the Bundesgerichtshof (Federal Court of Justice, Germany), which decided that the interpretation of Article 2 letter a) $)^{7}$, Article $3(1)^{8}$ and Article 5 (3) letters c) and

6 Judgement of ECJ (Grand Chamber) of 29 July 2019, Spiegel Online GmbH vs Volker Beck, C-516/17, ECLI:EU:C:2019:625.

7 Article 2 of Directive 2001/29, entitled "Reproduction Rights", reads as follows: "Member States shall provide for the exclusive right to authorise [a reproduction - G.T.] or prohibit direct or indirect, temporary or permanent reproduction by any means and in any form, in whole or in part: a) for authors, of their works; [...]".

8 Article 3 of Directive 2001/29, entitled "Right of communication to the public of works and right of making available to the public other subject-matter", states in paragraph 1: "Member States shall provide authors with the exclusive right to authorise or prohibit any communication to the public of their works [authorization for any public communication of their works - or the prohibition thereof], 
d) ${ }^{9}$ of Directive $2001 / 29^{10}$ read in the light of fundamental rights, in particular of freedom of information and of freedom of media, is not obvious and, therefore, it decided to stay the proceedings and to refer questions to the Court of Justice for a preliminary ruling.

In the proceedings between Funke Medien NRW GmbH and Bundesrepublik Deutschland, within the aspect analysed in this study concerning the mutual relationship of copyright and freedom of expression, questions two and three are the most important ones. Question three asked whether freedom of information and freedom of media, enshrined in Article 11 of the Charter of the Fundamental Rights of the European Union ${ }^{11}$, are capable of justifying, beyond the exceptions or limitations provided for in Article 5 (2) and (3) of Directive 2001/29, a derogation from the author's exclusive rights of reproduction and of communication to the public, referred to, respectively, in Article 2 letter a) and Article 3 (1) of that directive.

In its decision settling this issue, the Court decided that it is clear from Recital 32 of Directive 2001/29 that the list of exceptions and limitations contained in Article 5 of that directive is exhaustive ${ }^{12}$. The harmonisation effected by that directive aims to safeguard, in particular in the electronic environment, a fair balance between,

by wire or wireless means, including the making available to the public of their works in such a way that members of the public may access them from a place and at a time individually chosen by them".

9 Article 5 of Directive 2001/29, entitled "Exceptions and Limitations", states in paragraph 3 letters c) and d) and also in paragraph 5: "3. Member States may provide for exceptions or limitations to the rights provided for in Articles 2 and 3 in the following cases: [...] c) reproduction by the press, communication to the public or making available of published articles on current economic, political or religious topics or of broadcast works or other subject-matter of the same character, in cases where such use is not expressly reserved, and as long as the source, including the author's name, is indicated, or use of works or other subject-matter in connection with the reporting of current events, to the extent justified by the informatory purpose and as long as the source, including the author's name, is indicated, unless this turns out to be impossible; d) quotations for purposes such as criticism or review, provided that they relate to a work or other subject-matter which has already been lawfully made available to the public, that, unless this turns out to be impossible, the source, including the author's name, is indicated, and that their use is in accordance with fair practice, and to the extent required by the specific purpose; [...] 5. The exceptions and limitations provided for in paragraphs 1,2,3 and 4 shall only be applied in certain special cases which do not conflict with a normal exploitation of the work or other subject-matter and do not unreasonably prejudice the legitimate interests of the rightholder".

${ }^{10}$ Directive 2001/29/EC of the European Parliament and of the Council of 22 May 2001 on the harmonisation of certain aspects of copyright and related rights in the information society (OJ EU 2001, L 167, p. 10).

${ }^{11}$ OJ UE C 326/02, 26.10.2012, p. 1. Article 11 of the Charter in pargraphs 1 and 2 states: " 1 . Everyone has the right to freedom of expression. This right shall include freedom to hold opinions and to receive and impart information and ideas without interference by public authority and regardless of frontiers. 2. The freedom and pluralism of the media shall be respected".

12 This argument was also expressed in previous judgements. Cf. judgement of ECJ of 16 November 2016, Soulier i Doke, C-301/15, EU:C:2016:878, point 34; judgement of ECJ of 7 August 2018, Renckhoff, C-161/17, EU:C:2018:634, point 16. 
on the one hand, the interest of the holders of copyright and related rights in the protection of their intellectual property rights guaranteed by Article 17 (2) of the Charter ${ }^{13}$, and on the other hand, the protection of the interests and fundamental rights of users of protected subject matter, in particular their freedom of expression and information guaranteed by Article 11 of the Charter. The Court decided that to allow each Member State to derogate from an author's exclusive rights, referred to in Articles 2-4 of Directive 2001/29, beyond the exceptions and limitations, exhaustively set out in Article 5 of that directive, would endanger the effectiveness of the harmonisation of copyright and related rights effected by that directive, as well as the objective of legal certainty pursued by it ${ }^{14}$. Member States are required to apply those exceptions and limitations consistently. The requirement of consistency in the implementation of those exceptions and limitations could not be ensured if the Member States were free to provide for such exceptions and limitations beyond those expressly set out in Directive 2001/2915. In the light of the foregoing, with respect to the third preliminary question, the Court decided that freedom of information and freedom of media, enshrined in Article 11 of the Charter, are not capable of justifying, beyond the exceptions or limitations provided for in Article 5 (2) and (3) of Directive 2001/29, a derogation from the author's exclusive rights of reproduction and of communication to the public, referred to in Article 2 letter a) and Article 3 (1) of Directive respectively.

The second question was to determine whether, in interpreting the exceptions to the rights of the users of protected subject matter referred to in Article 5 (3) letter c), second case, and in Article 5 (3) letter d) of Directive, a national court can undertake an interpretation which takes full account of the need to respect freedom of expression and freedom of information, enshrined in Article 11 of the Charter.

Answering the question, the Court stated that transposing the exceptions and limitations referred to in Article 5 (2) and (3) of Directive 2001/29, the Member States are to ensure that they rely on an interpretation of those exceptions and limitations which allows for a fair balance to be struck between the various fundamental rights protected by the EU legal order. The authorities and courts of the Member States must not only interpret their national law in a manner consistent with that directive but also make sure that they do not rely on an interpretation of it which would be in conflict with those fundamental rights or with the other general principles of EU law ${ }^{16}$.

13 Article 17 (2) of the Charter states: "Intellectual property shall be protected".

${ }^{14}$ Similarly: judgement of ECJ of 13 February 2014, Svensson $i$ in., C-466/12, EU:C:2014:76, points 34 and 35 .

15 Similarly: judgement of ECJ of 12 November 2015, Hewlett-Packard Belgium, C-572/13, EU:C:2015:750, points 38 and 39.

${ }^{16}$ Similarly: judgement of ECJ of 29 January 2008, Promusicae, C-275/06, EU:C:2008:54, point 70; judgement of ECJ of 27 March 2014, UPC Telekabel Wien, C-314/12, EU:C:2014:192, point 46; judgement of ECJ of 16 July 2015, Coty Germany, C-580/13, EU:C:2015:485, point 34. 
In the mentioned judgement, the Court clearly allows interference in the rights of copyright holders under copyright and related rights by stating:

[...] it should be added that the protection of intellectual property rights is indeed enshrined in Article 17 (2) of the Charter. There is, however, nothing whatsoever in the wording of that provision or in the Court's case-law to suggest that that right is inviolable and must for that reason be protected as an absolute right ${ }^{17}$.

Answering the question, the Court referred to the view expressed in the caselaw of the ECHR, citing the judgement in the proceedings between Ashby Donald and others and France, when the ECHR, in particular, stressed the need to take into account the fact that the nature of the "speech" or information at issue is of particular importance, i.a. in political discourse and discourse concerning matters of the public interest. The judgement stated that exceptions to copyright (Article 5 (3) letters c) and d) of Directive 2001/29) are aimed at favouring the exercise of the right to freedom of expression by the users of protected subject matter and to freedom of media, enshrined in Article 11 of the Charter. In that regard, it should be noted that, in so far as the Charter contains rights which correspond to those guaranteed by the Convention for the Protection of Human Rights and Fundamental Freedoms, signed at Rome on 4 November 1950 (hereinafter: ECHR).

Article 11 of the Charter contains rights which correspond to those guaranteed by Article 10 (1) ECHR ${ }^{18}$. However, Article 52 (3) of the Charter ${ }^{19}$ and seeks to ensure the necessary consistency between the rights contained in it and the corresponding rights guaranteed by the ECHR. In the light of the foregoing, the Court in its answer to the second question decided that in striking the balance which is incumbent on a national court between the exclusive rights of the author referred to in Article 2 letter a) and in Article 3 (1) of Directive 2001/29 on the one hand, and, on the other one, the rights of the users of protected subject matter referred to in Article 5 (3) letter c), second case, and letter d) of Directive, the latter of which derogate from the former, a national court must, having regard to all the circumstances of the case before it, rely on an interpretation of those provisions which, whilst consistent with their wording and safeguarding their effectiveness, fully adheres to the fundamental rights enshrined in the Charter.

17 Similarly: judgement of ECJ of 24 November 2011, Scarlet Extended, C-70/10, EU:C:2011:771, point 43; judgement of ECJ of 16 February 2012, SABAM, C-360/10, EU:C:2012:85, point 41; judgement of ECJ of 27 March 2014, UPC Telekabel Wien, C-314/12, EU:C:2014:192, point 61.

18 Similarly: judgement of ECJ of 14 February 2019, Buivids, C-345/17, EU:C:2019:122, point 65 and the decisions cited therein.

19 Article 52 (3) of the Charter states: "In so far as this Charter contains rights which correspond to rights guaranteed by the Convention for the Protection of Human Rights and Fundamental Freedoms, the meaning and scope of those rights shall be the same as those laid down by the said Convention. This provision shall not prevent Union law providing more extensive protection". 


\section{FREEDOM OF EXPRESSION AS A CONSTRUCT OF THE CURRENT COPYRIGHT LAW}

Current legal literature indicated that the construct of copyright law contains a mechanism protecting public interest, including among others the protection of freedom of expression; the following regulations of the Polish author copyright and related rights are highlighted:

a) exclusion of the protection of concepts and other elements of a work defined in Article $1\left(2^{1}\right)$ of the copyright law,

b) content of provisions on permissible use,

c) time limitation of the duration of the author's material rights,

d) exclusion of certain works as defined in Article 4 of the copyright law from the cover of copyright law ${ }^{20}$.

The need to limit copyright within this area was accurately justified by a German expert on copyright, J. Kohler, stated that "not every use of a non-material good belonging to an author can be reserved for them: it would stifle human relationships and destroy freedom of creation"21.

In the light of the decisions of the ECJ under discussion here, any exclusions from the exclusive right of authors to reproduce and publicly communicate their works which is based on freedom of information and freedom of media can be justified only in cases enumerated in Article 5 (3) letters c) and d) of Directive ${ }^{22}$. In the Polish copyright and neighbouring rights law ${ }^{23}$, those exclusions are implemented in the content of Chapter 3 Division 3 of the Act, entitled "Permissible Use of Protected Works", from Article 23 to 35.

An analysis of legal literature describing court proceedings dealing with a collision of freedom of expression and copyright law can identify two kinds of situations:

1. Factual circumstances in which referring to freedom of expression will lead to a situation when the use of someone else's work violating provisions of copyright law is not be considered as illegal. Such decisions were made, among others, in the case Ashdown vs Telegraph Group Ltd ${ }^{24}$, which dealt

20 J. Barta R. Markiewicz, Prawo autorskie, Warszawa 2016 (Rozdział 5: Prawo autorskie a swoboda wypowiedzi, LEX/el. 2019).

${ }^{21}$ J. Kohler, Urheberrecht an Schriftwerken und Verlagsrecht, Aalen 1980, p. 171, quoted after J. Marcinkowska, Dozwolony użtek w prawie autorskim. Podstawowe zagadnienia, „Zeszyty Naukowe Uniwersytetu Jagiellońskiego. Prace z Wynalazczości i Ochrony Własności Intelektualnej” 2004, nr 87, p. 29.

22 The content of these exclusions was given in footnote 7.

${ }^{23}$ Act of 4 February 1994 on copyright and related rights (consolidated text Journal of Laws 2019, item 1231).

${ }^{24}$ Judgement of the Royal Courts of Justice Strand in London of 18 July 2001, Ashdown vs Telegraph Group Ltd (2001, EWCA Civ 1142). 
with the admissibility of a publication of a note from a secret meeting with the Prime Minister about the merger of two parties (the Labour Party and the Liberals) although there was no prior communication of the work with the authorisation of the author, which is a prerequisite of permissible use. A similar case was the trial of the party accused of communicating on the Internet excerpts from the writings of the Founder of the Church of Scientology. In these proceedings, when dismissing the case, the Court of Appeal in the Hague, in the decision of 4 September $2003^{25}$ decided that copyright was violated but the possibility of its application was restricted by freedom of access to information. Analysing the case in the light of Article 10 (2) ECHR, the Court decided that non-publication of the texts was against the public interest because it is used by the Church of Scientology to maintain control over its members. It was stated that, in particular circumstances freedom of expression protected by Article 10 ECHR supersedes protection under copyright.

2. Factual circumstances deal with a situation when a reference to the provisions of copyright is used as an argument restricting freedom of expression (e.g. the decision of the District Court in Rotterdam of 10 April 1975, which prohibited the publishing of Mein Kampf by A. Hitler based on the privilege of copyright which, in that situation, belonged to the state $\left.{ }^{26}\right)$. A similar situation was also in the case discussed in this study, Funke Medien NRW GmbH vs Bundesrepublik Deutschland when the German State refused access to documents on the grounds of limitations under copyright.

Commenting on the decision in the proceedings between Funke Medien NRW $\mathrm{GmbH}$ and Bundesrepublik Deutschland, it can be said that the two aforementioned aspects of the influence of copyright on freedom of expression occurred at the same time. As far as the first aspect is concerned, it should be noted that the interpretation of the provisions of the Directive in the matters of Funke Medien NRW GmbH vs Bundesrepublik Deutschland and Spiegel Online Gmb vs Volker Beck, confirms the line of case-law set in the case of Ashdown vs Telegraph Group Ltd, according to which freedom of expression can be a factor restricting author's monopoly and legalizing violations of it. The importance of the above-mentioned decisions of the ECJ lies in the fact that they specify the range of this interference. From the perspective of the EU law, and therefore only of this part of copyright which is covered by the unification of the EU law ${ }^{27}$, the principle of freedom of expression provided by Article 11 of the Charter of Fundamental Rights can influence the interpretation of copyright law but only within the exceptions enumerated in Article 5 (3) letters c) and

\footnotetext{
${ }^{25}$ Information from J. Barta, R. Markiewicz, Prawo autorskie a swoboda wypowiedzi..., p. 20.

${ }^{26}$ Information from J. Barta R. Markiewicz, Prawo autorskie (Rozdział 5, LEX/el. 2019).

${ }^{27}$ For example, author's moral rights are not covered by the unification of EU law.
} 
d) of Directive. Secondly, as the ECJ noted, the conflict of copyright and freedom of expression must be settled only by means of an interpretation which allows for the conformity of copyright with the fundamental rights enshrined by the Charter. This approach suggested by the differs from the approach applied by the ECHR. In the decisions made in Strasbourg, the said problem was not perceived as a question of interpretation balancing both values but rather as a conflict of two precious values when, depending on the circumstances, one must prevail over the other. Within the aspect described in this study, it was a conflict of copyright understood as the right to property as understood by Protocol No. 1 to the ECHR ${ }^{28}$ and to freedom of expression as of Article 10 (1) ECHR ${ }^{29}$. The role of an authority (court) applying the ECHR was reduced to, among others, checking which of the conflicting values of the case should be given priority and when freedom of expression was not the prevailing one, it had to settle the following issue: was the interference in the freedom guaranteed by Article 10 ECHR admissible in view of Article 10 (2) of the Convention ${ }^{30}$.

Decisions of the ECJ in the analysed cases, when the conflict of values (copyright and freedom of expression) is to be settled by means of an interpretation of the provisions of copyright law, shed new light on this issue.

\section{INTERPRETATION OF PROVISIONS OF EU LAW AS A METHOD OF SEEKING BALANCE BETWEEN COPYRIGHT AND FREEDOM OF EXPRESSION}

In legal literature, the concept of an interpretation of provisions of law is defined as "all considerations aiming to decode legal norms contained in current legal regulations and to determine their meaning" $"$. The discussed decisions of the ECJ

${ }^{28}$ Article 1 of the Protocol to the Convention for the Protection of Human Rights and Fundamental Freedoms Signed in Paris on 20 March 1952 and in Strasbourg on 16 September 1963 states: "Protection of property. Every natural or legal person is entitled to the peaceful enjoyment of his possessions. No one shall be deprived of his possessions except in the public interest and subject to the conditions provided for by law and by the general principles of international law [...]".

${ }^{29}$ Article 10 (1) of the Convention states: "Everyone has the right to freedom of expression. This right shall include freedom to hold opinions and to receive and impart information and ideas without interference by public authority and regardless of frontiers. This Article shall not prevent States from requiring the licensing of broadcasting, television or cinema enterprises".

${ }^{30}$ Article 10 (2) ECHR requires that it be checked that any restrictions of the freedoms are prescribed by law and are necessary in a democratic society, in the interests of national security, territorial integrity or public safety, for the prevention of disorder or crime, for the protection of health or morals, for the protection of the reputation or rights of others, for preventing the disclosure of information received in confidence, or for maintaining the authority and impartiality of the judiciary.

31 A. Korybski, [in:] A. Korybski, L. Leszczyński, A. Pieniążek, Wstęp do prawoznawstwa, Lublin 2010, p. 165. 
stress that a characteristic feature of the exceptions listed in Article 5 of Directive is that two legal norms are coded, which are in mutual opposition. The first one - expressed in Article 11 of the Charter of Fundamental Rights - the principle of freedom of expression and freedom of media, and the other one, regulated by $\mathrm{Ar}$ ticle 17 (2) of the Charter of Fundamental Rights - the principle of the protection of intellectual property. The ECJ confirms that the provision of these norms is an equivalent of the principle of freedom of expression specified in Article 10 (1) ECHR and the principle of protection of property contained in Article 1 of Protocol No. 1 to the Convention for the Protection of Human Rights and Fundamental Values $^{32}$. Undoubtedly, the aforementioned norms are specific in their character and are different from other norms existing both in the European law and national legal systems, and because of this, they can be defined as the so-called rules of law.

As L. Leszczyński noted, a rule of law is understood as a legal provision distinguished from other ordinary legal provisions by its exceptional axiological, functional and hierarchical significance, it protects legal values situated at the top of the axiological hierarchy of the legislator, fundamental issues for the whole legal system or at least for one branch or division or section of law ${ }^{33}$. Contemporary legal literature states that:

[...] principles of law operate according to the "more or less" outline, that is they can be implemented to a larger or smaller degree. Their defeasibility is stressed with respect to the option not to apply a rule whose provisions apply to the circumstances of a given case because conflicting rules in the case seem to be more significant and therefore should be given priority ${ }^{34}$.

Therefore, the aforementioned considerations mean that invoking the principle of freedom of expression as circumstances restricting copyright cannot be understood broadly as a general clause but only as an element of an interpretation of these provisions of copyright which provide for the permissible use of protected works and are the result of a direct implementation of Article 3 (3) letters c) and d) of Directive.

The application of a rule of law even when it means the need for a creative interpretation of it, according to literature, is usually characterised by lesser freedom of the judge when making a decision than in the case of the application of, for example, general clauses. When interpreting the scope of meaning of provisions

${ }^{32}$ Article 1 of Protocol No. 1 to the ECHR states: "Protection of property. Every natural or legal person is entitled to the peaceful enjoyment of his possessions. No one shall be deprived of his possessions except in the public interest and subject to the conditions provided for by law and by the general principles of international law $[\ldots]$ ".

33 L. Leszczyński, G. Maroń, Pojęcie i treść zasad prawa oraz generalnych klauzul odsyłajacych. Uwagi porównawcze, „Annales UMCS sectio G (Ius)” 2013, nr 1, pp. 81-82. Cf. S. Wronkowska, M. Zieliński, Z. Ziembiński, Zasady prawa. Zagadnienia podstawowe, Warszawa 1974.

${ }^{34}$ L. Leszczyński, G. Maroń, op. cit., p. 82. 
of law, the starting point is the text of the normative act and the position of the judicature and jurisprudence and only then social evaluation. In the case of general clauses, the significance of the legal text which refers to non-legal values contained therein is weakened ${ }^{35}$.

With reference to the approach to the interpretation of exceptions under Article 5 of Directive as imposed by the ECJ, it should be noted that it should be done in a way characteristic for the interpretation of rules of law. Literature shows that among directives of systemic interpretation, a key position with reference to the interpretation of rules of law is the directive of forming the cohesion of the legal system in such a way that the meaning of a rule of law was formed in such a way that it does not prohibit the protection of conflicting values or values correlated with other rules of law. When interpreting provisions expressing a rule of law it is also necessary to reach for the rules of purpose and functionality and to determine its ratio legis, it is also helpful to refer to the social context and particularly to social consequences of the adoption of a specific meaning of the principle by the interpreter and to compare the understanding of the rule of law in other countries with the same legal culture or a principle existing in international law, e.g. decisions of Strasbourg or Luxembourg Courts, and referring to extra-legal axiology is not excluded ${ }^{36}$. As literature states: "[...] moral, political, economic values or values of a different provenance form instruments with the help of which an interpreting person can modify (narrow or broaden) the scope of meaning of the rule which emerges from a linguistic or systemic interpretation $[\ldots]^{\prime 37}$.

In my opinion, we can also expect that a consequence of the position of the ECJ expressed in the cases under analysis is that it will change the way of interpreting exceptions and limitations of copyright within permissible use performed with the so-called three-step test as of Article 5 (5) of Directive 2001/29 (Article 35 of the Polish Law on copyright and related rights). It is interesting that the ECJ's decisions did not refer to that issue. However, a practical application of the interpretation of exceptions to the author's monopoly described in Article 5 (3) of Directive, cannot be done irrespective of principles of the three-step test. The issue of the application of the three-step test raises many doubts in judicial and legal literature, it is worth mentioning the article entitled The Three-Step Test Revisited: How to Use the Test's Flexibility in National Copyright Law $w^{38}$, whose authors noticed that a practical application of the test must also consider the interests of other entities, including human rights and fundamental freedoms. In my opinion, a practical consequence

${ }^{35}$ Ibidem, p. 89.

36 Ibidem, p. 84.

37 Ibidem, p. 85.

${ }^{38}$ Ch. Geiger, D. Gervais, M. Senftleben, The Three-Step Test Revisited: How to Use the Test's Flexibility in National Copyright Law, "PIJIP Research Paper” 2013, No. 2013-04. 
of the discussed decisions of the ECJ will be that when applying the three-step test, the aspect of freedom of expression will be particularly considered.

There has been practically no doubt in current literature that provisions of permissible use of works, as they are an exception to the principle of author's monopoly, are case-based and in accordance with the principle exceptiones non sunt extendendae they should be interpreted strictly ${ }^{39}$. This statement, in light of the justification of the decisions of the ECJ under analysis, is not that obvious. As the ECJ noticed in points 69-71 of the justification to the judgement in the proceedings between Funke Medien NRW GmbH and Bundesrepublik Deutschland, any derogation from a general rule must, in principle, be interpreted strictly. However, although Article 5 of Directive 2001/29 is expressly entitled "Exceptions and limitations", it should be noted that those exceptions or limitations do themselves confer rights on the users of works or of other subject matter. In addition, that article is specifically intended, to ensure a fair balance between, on the one hand, the rights and interests of right holders, which must themselves be given a broad interpretation, and, on the other hand, the rights and interests of users of works or other subject matter. Thus, as the Court states, it follows that the interpretation of the exceptions and limitations provided for in Article 5 of Directive 2001/29 must allow their effectiveness (effet utile) to be to safeguarded and their purpose to be observed since such a requirement is of particular importance where those exceptions and limitations aim, as do those provided for in Article 5 (3) letters c) and d) of Directive 2001/29, to ensure observance of fundamental freedoms. This means that the ECJ allows a broad interpretation of the exceptions listed in Article 5 of Directive 2001/29 if that is necessary to observe fundamental rights.

With respect to the other aspect of the influence of copyright on freedom of expression, when provisions of copyright law are used as an argument restricting access to information, it should be noted that despite the fact that the Court in the judgements under analysis clearly stated that when interpreting provisions of copyright law concerning exceptions listed in Article 5 of Directive the obligation to protect freedom of information and of the media provided for by Article 11 of the Charter of Fundamental Rights, this does not change the fact that provisions of copyright law can still be used as an argument in favour of refusing access to or availability of certain works containing required information.

The question is whether provisions of the copyright law can still be used as an argument in favour of refusing access to information when access to information is based on the Act of 6 September 2001 on access to public information ${ }^{40}$ or Article 4

${ }^{39}$ Cf. J. Szczotka, [in:] M. Poźniak-Niedzielska (red.), J. Szczotka, M. Mozgawa, Prawo autorskie i prawa pokrewne. Zarys wyktadu, Bydgoszcz 2007, p. 83.

${ }^{40}$ Consolidated text Journal of Laws 2018, item 1330 as amended. 
in conjuction with Articles 11 and 49 of the Press Law ${ }^{41}$. According to the factual circumstances, which was the basis of the judgement in the proceedings between Funke Medien NRW GmbH and Bundesrepublik Deutschland, the Federal Republic of Germany refused to grant the press access to information on the grounds of copyright. As it is known, provisions allowing permissible use, which aim, among others, to ensure the principle of freedom of media and access to information, do not form claims making it possible to enforce their implementation.

Of course, if a given entity, e.g. the press, in one way or another obtains a work containing the desired information and publishes it, such behaviour may not be treated as an infringement of copyright (provided it happens within a situation of exceptions listed in Article 5 of Directive). While a work which contains the information belongs solely to the authorised person, provisions of permissible use or exceptions listed in Article 5 of Directive shall be insufficient to gain access to the work. It seems that, unfortunately, the discussed decisions do not change the present situation in this respect.

Because of lack of adequate claims, referring to the principle of freedom of expression (tight to obtain information) or to freedom of the media cannot justify a request for access to a work in order to realise a permissible use or a request that action be stopped when such permissible use is limited, for example, by an entity using technical means of protection of a work against copying or when an entity providing hosting services (services of posting content online) referring to an infringement of copyright blocks or removes a recording from an online sharing website, e.g. from YouTube. Polish legal literature provides a scientific discussion of this aspect in the context of an analysis of the legal structure of the provisions of the Polish law on the permissible use of protected works. It is worth noting here that in Polish literature permissible use, as an exception to the general principle of author's monopoly, has been understood in many different ways ${ }^{42}$. Conclusions from the analysis of the

${ }^{41}$ Act of 26 January 1984 - Press Law (Journal of Laws No. 5, item 24 as amended). Article 4 (1) of the Press Law states: „Entrepreneurs, entities not qualified to the public finances sector, and non-profit entities are obliged to give information to the press on their activity, unless such information is confidential or breaches the right to privacy under separate provisions". This regulation is supplemented by Article 11 (1) of the Press Law, which states: "A journalist is allowed to obtain information referred to in Article 4". Entities obliged to provide information in under the said rules are listed in Article 11 (2) of the Press Law. This rule says that "On behalf of the organizational units, information shall be provided by heads of the organizational units, their deputies, spokespersons or other authorized personnel within the limits of entrusted duties".

${ }^{42}$ The situation of an entity using works or items of related rights based on the provisions of permissible use in the Polish copyright law has always been perceived as an exception from the author's monopoly, whose nature and features, however, have been described differently by representatives of the Polish doctrine of law. More on the topics, see S. Ritterman, Komentarz do ustawy o prawie autorskim, Kraków 1938, p. 80; A. Kopff, Charakter i treść praw z art. 14 ustawy o prawie autorskim, „Nowe Prawo” 1967, nr 7-8, p. 893; S. Grzybowski, [in:] S. Grzybowski, A. Kopff, J. Serda, Zagad- 
justification of the discussed judgements of the ECJ make it possible to note that judgements of the ECJ are in conformity with opinions of representatives of the Polish doctrine of law who perceived permissible use not as an exercise of a subjective right ${ }^{43}$ but as a realization of natural freedom. Because the ECJ perceives exceptions from the author's monopoly listed in Article 5 of Directive as, among others, a realization of one of the natural freedoms, which is freedom of media and freedom of access to information. In this aspect, natural freedom should be understood as freedom of conduct, inherent and inalienable value, which can be realized according to the will of an entitled entity. A normative act which guarantees the existence of given freedom is only declarative and not constitutive in character ${ }^{44}$. It is a duty of the state to protect given freedom, a normative act does not create the freedom, it can only declare (enumerate) it as a value under special protection or, possibly, indicate ways of settling conflicts between particular values.

As was mentioned before, the analysis of court decisions shows that in some situations copyright law can be used as an argument restricting access to materials containing specific essential information. It is also worth mentioning that this aspect of influence of copyright law, as an instrument restricting freedom of expression was noticed by the EU legislator and somewhat regulated by the provisions of Article 17 of Directive (EU) 2019/790 of the European Parliament and of the Council of 17 April 2019 on copyright and related rights in the Digital Single Market and amending Directives 96/9/EC and 2001/29/EC ${ }^{45}$.

The Directive (EU) 2019/790 states that monitoring the legality of contents uploaded by users of Internet websites cannot prevent access to the works or other

nienia prawa autorskiego, Warszawa 1973, p. 60; J. Błeszyński, Prawo autorskie, Warszawa 1988, p. 133; W. Machała, Dozwolony użytek chronionych utworów w polskim prawie autorskim w świetle cywilistycznej koncepcji prawa podmiotowego, „Zeszyty Naukowe Uniwersytetu Jagiellońskiego. Prace z Wynalazczości i Ochrony Własności Intelektualnej” 2001, nr 78, p. 54 ff.; J. Marcinkowska, op. cit., pp. 133-134.

43 W. Machała, op. cit., p. 54 ff.; J. Marcinkowska, op. cit., pp. 133-134.

${ }^{44}$ Constitutional law describes freedom also as a sphere of the activity of an entity, which is not prohibited by the legislator and within which the entity can act feely. Freedom can be presented as a natural sphere of human activity in which acts of their free will are realised and they are legally indifferent. Restrictions of freedom must satisfy the requirements of Article 31 of the Constitution of the Republic of Poland of 2 April 1997 (Journal of Laws 1997, No. 78, item 483 as amended). Cf. B. Banaszak, Ogólne wiadomości o prawach człowieka, [in:] Prawa i wolności obywatelskie w Konstytucji RP, red. B. Banaszak, A. Preisner, Warszawa 2002, p. 18; L. Wiśniewski, Prawo a wolność człowieka - pojęcie i konstrukcja prawna, [in:] Podstawowe prawa jednostki i ich sądowa ochrona, red. L. Wiśniewski, Warszawa 1997, p. 58; M. Augustyniak, Pojęcie, istota oraz geneza wolności i praw człowieka, [in:] Wolności i prawa człowieka w Konstytucji Rzeczypospolitej Polskiej, red. M. Chmaj, Warszawa 2008, p. 11; J. Ciapała, Wolność a uprawnienie-próba analizy porównawczej pojęć w kontekście wybranych postanowień Konstytucji RP, „Humanistyczne Zeszyty Naukowe Prawa Człowieka" 2000, nr 7, p. 77.

${ }^{45}$ OJ L 130/92, 17.05.2019. 
subject matter uploaded by users, covered by an exception based on current regulations, and can be publicly used without obtaining permission from authorised entities within permissible use such as quotation, criticism, review, use for the purpose of caricature, parody or pastiche. Article 17 (9) of Directive (EU) 2019/790 requires that Member States shall provide that online content-sharing service providers put in place an effective and expeditious complaint and redress mechanism that is available to users of their services in the event of disputes over the disabling of access to, or the removal of, works or other subject matter uploaded by them. The said provision states that: "Complaints submitted under the mechanism provided for in the first subparagraph shall be processed without undue delay, and decisions to disable access to or remove uploaded content shall be subject to human review". Member States must also ensure that out-of-court redress mechanisms are available for the settlement of disputes and that users have access to a court or another relevant judicial authority to assert the use of an exception or limitation to copyright and related rights.

\section{CONCLUSION}

Summing up the foregoing considerations, the judgement given in the proceedings between Funke Medien NRW GmbH and Bundesrepublik Deutschland and the coincident judgement in the case Spiegel Online GmbH vs Volker Beck, which have been discussed in this study, will set up a new way of perceiving the conflict between the provisions of copyright and freedom of expression. There should be no doubt now that a departure from the provisions of copyright in favour of the protection of the value of freedom of expression is permissible. This departure can occur only in cases enumerated in Article 5 (3) letters c) and d) of Directive 2001/29. The conflict between the values on the basis of the provisions of EU law can be solved by such an interpretation of the provisions of copyright law which will ensure their conformity with fundamental rights enshrined by the Charter of Fundamental Rights. It should be assumed that the analysed decisions of the ECJ will also influence significantly the performance of the three-step test, which is described in Article 5 (5) of Directive 2001/29 (Article 35 of the Polish Act on copyright and related rights) and the possibility of breaking the principle exceptiones non sunt extendendae with reference to the provisions of permissible use if that is the condition of observing fundamental rights.

Despite the enormous importance of the regulations described herein for the interpretation of the provisions of copyright, it should be remembered that there exists another sphere of influence of copyright law on freedom of expression, which is not covered directly by the analysed judgements of the ECJ and which deals with the issue of access to information and disabling contents on online pages with the assumption of the obligation to respect copyright. As was shown in this article, 
this aspect needs particular regulations, Article 17 of Directive (EU) 2019/790 of 17 April 2019 on copyright and related rights in the Digital Single Market and amending Directives 96/9/EC and 2001/29/EC is devoted to it. As this study has shown, the decisions of the ECJ commented-on in herein will determine the perception of provisions on the permissible use of works and will be of significant importance for the implementation of Directive of (EU) 2019/790 on copyright and related rights in the Digital Single Market into national legal systems of the Member States. The influence of the decisions of the ECJ described herein on the decision of the Strasbourg Court cannot be overestimated.

\section{REFERENCES}

Act of 26 January 1984 - Press Law (Journal of Laws No. 5, item 24 as amended).

Act of 4 February 1994 on copyright and related rights (consolidated text Journal of Laws 2019, item 1231).

Act of 6 September 2001 on access to public information (consolidated text Journal of Laws 2018, item 1330 as amended).

Augustyniak M., Pojęcie, istota oraz geneza wolności i praw człowieka, [in:] Wolności i prawa człowieka w Konstytucji Rzeczypospolitej Polskiej, red. M. Chmaj, Warszawa 2008.

Banaszak B., Ogólne wiadomości o prawach człowieka, [in:] Prawa i wolności obywatelskie w Konstytucji RP, red. B. Banaszak, A. Preisner, Warszawa 2002.

Barta J., Markiewicz R., Prawo autorskie, Warszawa 2016.

Barta J., Markiewicz R., Prawo autorskie a swoboda wypowiedzi i twórczości, [in:] Współczesne problemy prawa handlowego. Księga jubileuszowa dedykowana prof. dr hab. Marii Poźniak-Niedzielskiej, red. A. Kidyba, R. Skubisz, Warszawa 2007.

Błeszyński J., Prawo autorskie, Warszawa 1988.

Charter of the Fundamental Rights of the European Union (OJ UE C 326/02, 26.10.2012, p. 1).

Ciapała J., Wolność a uprawnienie - próba analizy porównawczej pojęć w kontekście wybranych postanowień Konstytucji RP, „Humanistyczne Zeszyty Naukowe-Prawa Człowieka” 2000, nr 7.

Constitution of the Republic of Poland of 2 April 1997 (Journal of Laws 1997, No. 78, item 483 as amended).

Danay R., Jacob R., Copyright vs. Free Expression: The Case of Peer-to-Peer File-Sharing of Music in the United Kingdom, "8 Yale Journal of Law \& Technology" 2005, No. 32.

Decision of ECHR of 10 January 2013 in the case Ashby Donald and others vs France, complaint No. $36769 / 08$.

Directive 2001/29/EC of the European Parliament and of the Council of 22 May 2001 on the harmonisation of certain aspects of copyright and related rights in the information society (OJ EU 2001 L 167, p. 10).

Directive (EU) 2019/790 of the European Parliament and of the Council of 17 April 2019 on copyright and related rights in the Digital Single Market and amending Directives 96/9/EC and 2001/29/ EC (OJ EU L 130/92, 17.05.2019).

European Convention for the Protection of Human Rights and Fundamental Freedoms of 4 November 1950 (Journal of Laws 1993, No. 61, item 284 as amended).

Geiger Ch., Gervais D., Senftleben M., The Three-Step Test Revisited: How to Use the Test's Flexibility in National Copyright Law, "PIJIP Research Paper" 2013, No. 2013-04. 
Grzybowski S., [in:] S. Grzybowski, A. Kopff, J. Serda, Zagadnienia prawa autorskiego, Warszawa 1973.

Judgement of the Royal Courts of Justice Strand in London of 18 July 2001, Ashdown vs Telegraph Group Ltd (2001, EWCA Civ 1142).

Judgement of ECJ of 29 January 2008, Promusicae, C-275/06, EU:C:2008:54.

Judgement of ECJ of 24 November 2011, Scarlet Extended, C-70/10, EU:C:2011:771.

Judgement of ECJ of 16 February 2012, SABAM, C-360/10, EU:C:2012:85.

Judgement of ECJ of 13 February 2014, Svensson $i$ in., C-466/12, EU:C:2014:76.

Judgement of ECJ of 27 March 2014, UPC Telekabel Wien, C-314/12, EU:C:2014:192.

Judgement of ECJ of 16 July 2015, Coty Germany, C-580/13, EU:C:2015:485.

Judgement of ECJ of 12 November 2015, Hewlett-Packard Belgium, C-572/13, EU:C:2015:750.

Judgement of ECJ of 16 November 2016, Soulier i Doke, C-301/15, EU:C:2016:878.

Judgement of ECJ of 7 August 2018, Renckhoff, C-161/17, EU:C:2018:634.

Judgement of ECJ of 14 February 2019, Buivids, C-345/17, EU:C:2019:122.

Judgement of ECJ (Grand Chamber) of 29 July 2019, Funke Medien NRW GmbH vs Bundesrepublik Deutschland, C-469/17, ECLI:EU:C:2019:623.

Judgement of ECJ (Grand Chamber) of 29 July 2019, Spiegel Online GmbH vs Volker Beck, C-516/17, ECLI:EU:C:2019:625.

Kohler J., Urheberrecht an Schriftwerken und Verlagsrecht, Aalen 1980.

Kopff A., Charakter i treść praw z art. 14 ustawy o prawie autorskim, „Nowe Prawo” 1967, nr 7-8.

Korybski A., [in:] A. Korybski, L. Leszczyński, A. Pieniążek, Wstęp do prawoznawstwa, Lublin 2010.

Leszczyński L., Maroń G., Pojęcie i treść zasad prawa oraz generalnych klauzul odsyłających. Uwagi porównawcze, „Annales UMCS sectio G (Ius)” 2013, nr 1.

Machała W., Dozwolony użytek chronionych utworów w polskim prawie autorskim $w$ świetle cywilistycznej koncepcji prawa podmiotowego, „Zeszyty Naukowe Uniwersytetu Jagiellońskiego. Prace z Wynalazczości i Ochrony Własności Intelektualnej” 2001, nr 78.

Marcinkowska J., Dozwolony użtek w prawie autorskim. Podstawowe zagadnienia, „Zeszyty Naukowe Uniwersytetu Jagiellońskiego. Prace z Wynalazczości i Ochrony Własności Intelektualnej” 2004, nr 87.

Ritterman S., Komentarz do ustawy o prawie autorskim, Kraków 1938.

Szczotka J., [in:] M. Poźniak-Niedzielska (red.), J. Szczotka, M. Mozgawa, Prawo autorskie i prawa pokrewne. Zarys wyktadu, Bydgoszcz 2007.

Voorhoof D., Copyright vs. freedom of expression, http://echrblog.blogspot.com/2013/01/copyright-vs-freedom-of-expression.html [access: 5.08.2019].

Wiśniewski L., Prawo a wolność człowieka - pojęcie i konstrukcja prawna, [in:] Podstawowe prawa jednostki i ich sądowa ochrona, red. L. Wiśniewski, Warszawa 1997.

Wronkowska S., Zieliński M., Ziembiński Z., Zasady prawa. Zagadnienia podstawowe, Warszawa 1974.

\section{STRESZCZENIE}

Dyskusja publiczna z 2018 r. dotycząca uchwalenia przez Parlament Europejski dyrektywy w sprawie prawa autorskiego i praw pokrewnych na jednolitym rynku cyfrowym, nazywanej w dyskursie publicznym mianem ACTA 2, budziła ogromne emocje społeczne. U źródła tego konfliktu leżały dwie zderzające się ze sobą wartości: potrzeba ochrony praw autorskich i zabezpieczenia interesów ekonomicznych twórców oraz wolność wypowiedzi (wolność internetu), szczególnie istotna dla użytkowników utworów i użytkowników internetu. Wydane przez Trybunał Sprawiedliwości Unii Europejskiej w dniu 29 lipca 2019 r. orzeczenia w sprawie Funke Medien NRW GmbH przeciwko Bundesrepublik Deutschland oraz zbieżne z nim orzeczenie w sprawie Spiegel Online GmbH prze- 
Pobrane z czasopisma Studia Iuridica Lublinensia http://studiaiuridica.umes.pl Data: 26/04/2023 11:31:40

ciwko Volkerowi Beckowi dotyczy wskazanego wyżej konfliktu wartości. Niniejszy artykuł zawiera opis głównych tez wskazanych wyżej rozstrzygnięć TSUE oraz wskazuje na ich konsekwencje W zakresie zmiany dotychczasowego sposobu interpretacji przepisów prawa autorskiego. W artykule zamieszczono także uwagi dotyczące wpływu tych rozstrzygnięć i ich konsekwencji w zakresie naruszającego wolność wypowiedzi blokowania treści przez podmioty świadczące usługi hostingowe w świetle wymagań nowej dyrektywy z dnia 17 kwietnia 2019 r. Ponadto wskazano argumenty świadczące o tym, że dyrektywa 2019/790/WE Parlamentu Europejskiego i Rady z dnia 17 kwietnia 2019 r. w sprawie prawa autorskiego i praw pokrewnych na jednolitym rynku cyfrowym oraz nowy, wytyczony w komentowanych orzeczeniach TSUE, sposób interpretacji przepisów prawa autorskiego istotnie zmienił dotychczasowy sposób postrzegania przepisów o dozwolonym użytku utworów.

Słowa kluczowe: prawo autorskie; prawa człowieka; swoboda wypowiedzi; własność intelektualna 